\title{
INVENTARISASI LAHAN PERTANIAN DI KABUPATEN SIDOARJO MENGGUNAKAN CITRA SATELIT MULTITEMPORAL
}

\author{
Wisnu Pribadi, Teguh Hariyanto \\ Program Studi Teknik Geomatika FTSP-ITS, Kampus ITS Sukolilo, Surabaya, 60111 \\ Email : teguh_hr@geodesy.its.ac.id
}

\begin{abstract}
Abstrak
Kabupaten Sidoarjo sebagai salah satu penyangga Ibukota Propinsi Jawa Timur merupakan daerah yang mengalami perkembangan pesat. Keberhasilan ini dicapai karena berbagai potensi yang ada di wilayahnya seperti industri pertanian dan perdagangan, pariwisata, serta usaha kecil dan menengah dapat dikemas dengan baik dan terarah. Kabupaten Sidoarjo memiliki luas daerah 71,424.3 km2 dengan luas sawah 23,566 dimana sektor pertanian selalu menjadi komoditas yang diunggulkan. Penelitian dilakukan secara multitemporal dengan menggunakan kemampuan sensor pada citra untuk melakukan pengambilan data pada daerah yang sama pada tempo yang telah ditetapkan.
\end{abstract}

Metode yang digunakan dalam penelitian ini adalah aplikasi penginderaan jauh dengan pengolahan citra untuk memperoleh luas lahan pertanian di Kabupaten Sidoarjo. Data yang digunakan adalah citra satelit Landsat ETM 7 dan ALOS AVNIR-2. Proses pengolahan citra menggunakan metode klasifikasi terbimbing dengan alghoritma Normalized Difference Vegetation Index (NDVI).

Hasil penelitian ini menunjukkan bahwa luas tutupan lahan pertanian tahun 2000 sebesar 15.858 ha dan tahun 2005 sebesar 15850,44 ha. Sehingga terjadi penyusutan luas tutupan lahan pertanian sebesar 7,56 ha. Sedangkan luas tutupan lahan pertanian tahun 2010 sebesar 11.337,55 ha. Dibandingkan dengan luas tutupan lahan tahun 2005, telah terjadi penyusutan luas sebesar 4512.89 ha pada tahun 2010

Kata Kunci : Landsat-7 ETM, ALOS AVNIR-2 , Lahan Pertanian, Kabupaten Sidoarjo

\section{PENDAHULUAN}

\section{Latar Belakang}

Kabupaten Sidoarjo sebagai salah satu penyangga Ibukota Propinsi Jawa Timur merupakan daerah yang mengalami perkembangan pesat. Pada sektor pertanian selalu diunggulkan dan menjadi komoditas pada daerah tersebut. Kabupaten Sidoarjo memiliki luas daerah 714,243 km dengan luas sawah $23566 \mathrm{Ha}$ (2005) (Dinas Pertanian, Perkebunan dan Peternakan Kabupaten Sidoarjo).

Pemanfaatan teknologi penginderaan jauh di Indonesia perlu lebih dikembangan dan diaplikasikan untuk mendukung efisiensi pelaksanaan inventarisasi sumberdaya lahan/tanah dan identifikasi penyebaran karakteristik lahan pertanian terutama pada wilayah sentra produksi pangan. Dengan memanfaatkan citra satelit Landsat dan ALOS AVNIR-2 yang digunakan untuk memonitoring area sawah Kabupaten Sidoarjo. Citra satelit ALOS AVNIR-2 yang digunakan secara multitemporal yaitu data citra satelit ALOS AVNIR-2 2010 yang akan digunakan membandingkan perubahan area sawah pada tahun sebelumnya yaitu tahun 2000 dan 2005 dengan citra Landsat. Sifat data multitemporal adalah kemampuan sensor pada citra untuk melakukan pengulangan penyapuan suatu daerah tertentu yang telah ditetapkan. Penyapuan tersebut dilakukan pada periode tertentu (per bulan atau per tahun), sehingga dapat digunakan untuk melakukan monitoring perubahan area pada daerah pada periode tertentu.

\section{Perumusan Masalah}

Permasalahan dalam penelitian ini adalah bagaimana mengolah citra Landsat dan ALOSAVNIR 2 secara kuantitatif, agar bisa digunakan untuk mengetahui perubahan luasan sawah di Kabupaten Sidoarjo.

\section{Batasan Masalah}

Batasan masalah dari penelitian ini sebagai berikut: 
1. Wilayah studi adalah Kabupaten Sidoarjo, Jawa Timur

2. Citra yang digunakan adalah citra Landsat tahun 2000 dan tahun 2005 serta ALOS AVNIR-2 tahun 2010.

3. Peta yang digunakan adalah peta topografi Kabupaten Sidoarjo tahun 1999 dengan skala 1: 25.000 terbitan BAKOSURTANAL (Badan Koordinasi Survey dan Pemetaan Nasional)

4. Objek dari penelitian ini adalah lahan sawah di Kabupaten Sidoarjo, Jawa Timur.

5. Hasil dari penelitian ini adalah berupa evaluasi perubahan area sawah pada tahun 2000, 2005 dan 2010

\section{Tujuan Penelitian}

Tujuan penelitian ini adalah :

1. Mengetahui luas area sawah dari data citra satelit tahun 2000, 2005 dan 2010.

2. Memonitor perubahan luas area sawah pada tahun 2000, 2005 dan 2010.

\section{METODOLOGI PENELITIAN}

\section{Lokasi Penelitian}

Lokasi penelitian ini akan dilakukan di daerah Kabupaten Sidoarjo, Jawa Timur.

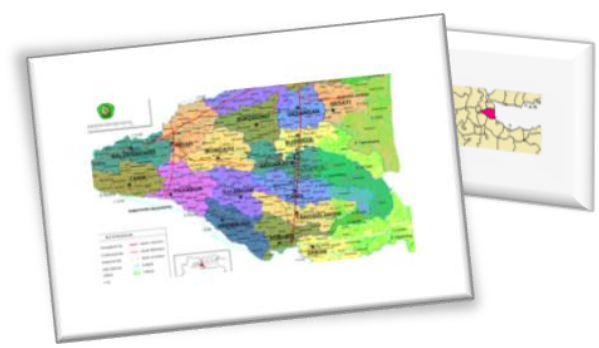

Gambar 1. Lokasi Penelitian

\section{Data Dan Peralatan}

\section{- Data}

Data yang digunakan dalam penelitian ini adalah:

1. Data citra satelit Landsat 7 bulan Agustus 2000 (Ortorektifikasi) dan bulan April 2005, serta ALOS-AVNIR 2 bulan September 2010

\section{- Peralatan}

Peralatan yang digunakan dalam penelitian ini adalah:

1. Perangkat Keras (Hardware)
a. Laptop

2. Perangkat Lunak (Software)
a. ENVI 4.6.1
b. ER MAPPER 7.0

\section{Diagram Alir Pengolahan Data}

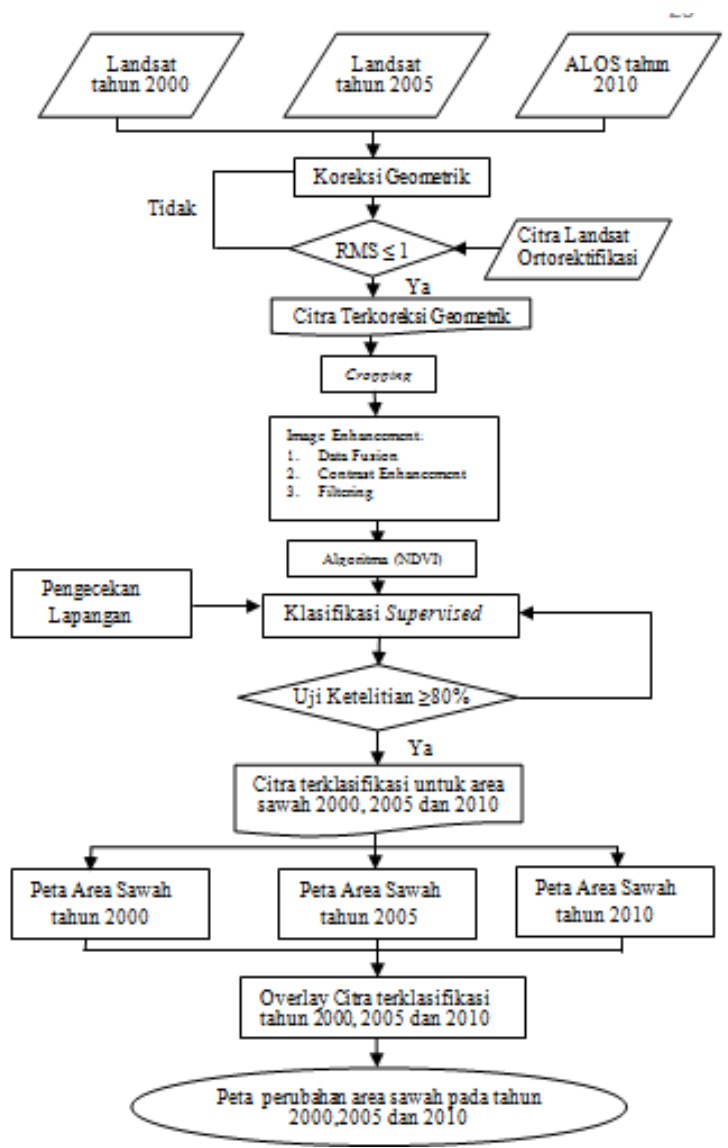

Gambar 2. Diagram Tahap Pengolahan Data

Penjelasan dari diagram alir penelitian di atas adalah :

1. Koreksi Geometrik

Scene citra satelit yang masih dalam bentuk raw data masih mengandung kesalahan geometrik (belum mempunyai koordinat yang tepat), dari akibat inilah citra yang dihasilkan belum dapat dipergunakan sebagai peta, oleh karena itu kesalahan ini harus direduksi dengan cara :

a. Registrasi yaitu koreksi geometrik antara citra yang belum terkoreksi dengan citra yang sudah terkoreksi atau antara citra dengan peta. Teknik ini dilakukan jika diperlukan georeferencing (posisi citra disamakan dengan koordinat peta atau koordinat bumi). Apabila tidak diperlukan georeferencing, registrasi dapat dilakukan 
terhadap citra lain yang digunakan sebagai referensi.

b. Rektifikasi yaitu koreksi geometrik antara citra dengan peta. Koreksi geometrik yang bersifat random diselesaikan dengan analisa titik kontrol tanah (ground control point) melalui fungsi transformasi yang menghubungkan antara sistem koordinat tanah dan citra. Untuk rektifikasi citra Landsat, data acuan yang digunakan cukup dengan peta rupa bumi skala $1: 25.000$

2. Pemotongan Citra (Cropping)

Daerah penelitian yang terliput dalam citra, perlu dilakukan proses pemotongan (cropping) untuk mendapatkan citra digital yang hanya meliputi daerah penelitian, supaya pemrosesan data menjadi lebih efektif. Proses pemotongan citra secara sederhana dilakukan dengan menampilkan citra berdasarkan masukan koordinat geografis yang membatasi daerah penelitian

3. Penajaman Citra (Image Enhancement)

a. Data Fusion: Menggabungkan dua citra dengan area yang sama

b. Contrast Enhancement : Mengatur pencahayaan pada citra

c. Filtering : Memperbaiki tampilan citra dengan mentransformasi nilai-nilai digital citra seperti mempertajam batas area yang mempunyai nilai digital yang sama

4. Klasifikasi Citra

Untuk Klasifikasi ini menggunakan algoritma [NDVI=(NIR - VIS) / ( NIR + VIS ). Pengklasifikasian bertujuan Untuk Mengelompokan Penampakan Citra kedalam beberapa kelas yang didasari nilai reflektansi setiap objek. Pada pengolahan citra ini akan dilakukan pengklasifikasian dengan menggunakan teknik supervised classification

\section{HASIL DAN PEMBAHASAN}

\section{Hitungan SoF}

$$
\text { Besar SoF }=\frac{\left[\text { Trace }\left(\mathrm{A}^{\mathrm{T}} \cdot \mathrm{A}\right)^{-1}\right]}{\text { Jumla h Parameter }}
$$

Semakin kecil bilangan faktor kekuatan jaring, maka akan semakin baik konfigurasi jaring yang bersangkutan, dan sebaliknya (Abidin, 2000). Besar SoF yang dihasilkan jaring tersebut mendekati nol sehingga desain jaring SoF dianggap kuat.
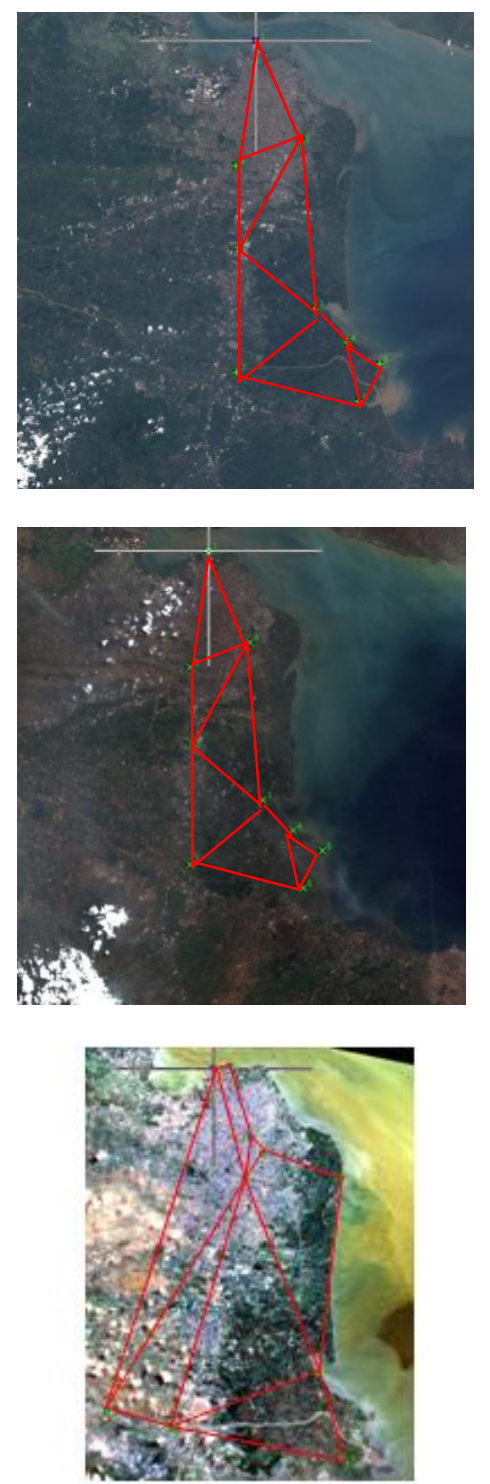

Gambar 3. Desain jaring pada tiap citra

\section{Koreksi Geometrik dan Strength Of Figure}

Koreksi geometrik dilakukan dengan memberikan titik control permukaan atau biasa disebut dengan ground control point (GCP) dari citra referensi landsat-7 ETM orthorektifikasi pada citra yang sudah terkoreksi dan diproses dengan menggunkan menu Geocoding Wizard pada perangkat lunak ER Mapper 7.0 
Sistem proyeksi yang digunakan adalah Universal Transverse Mercator zona 49s dan datum yang dipakai adalah WGS 1984. Nilai RMSerror ratarata untuk koreksi geometrik dari masing-masing citra dapat dilihat pada table di bawah ini:

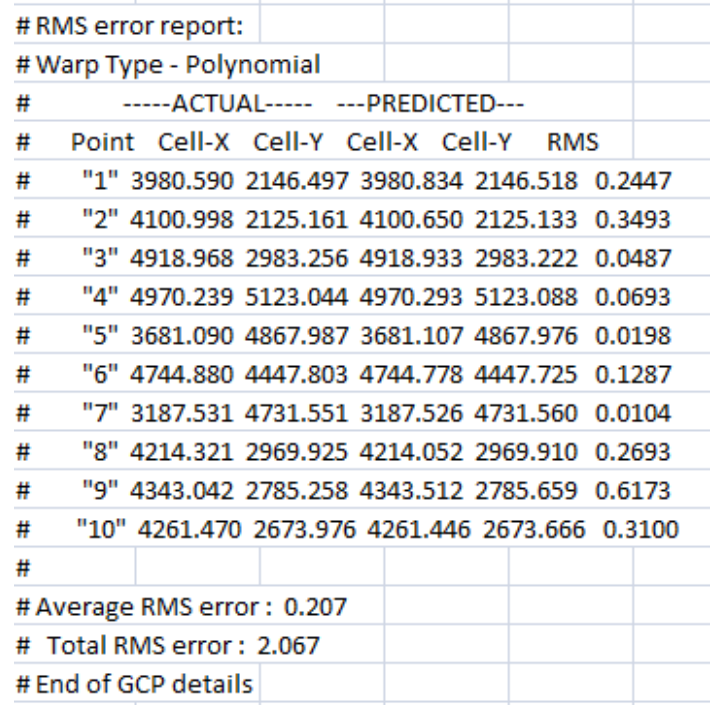

Gambar 4. Hasil RMS Koreksi Geometrik Landsat 7 ETM 2000 Orthorektifikasi dengan Landsat 7 ETM 2005

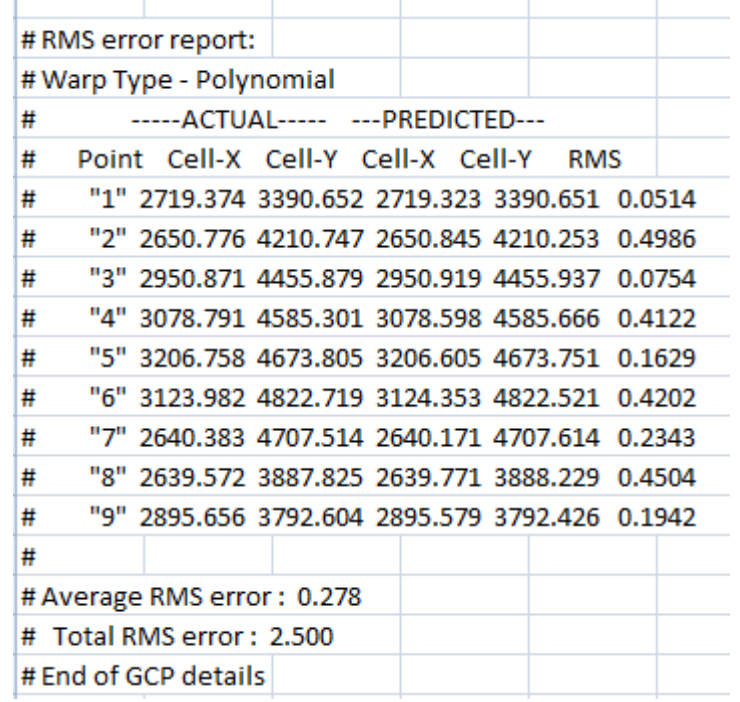

\section{Gambar 5. Hasil RMS Koreksi Geometrik Landsat 7 ETM 2000 Orthorektifikasi dengan ALOS 2010}

\section{Cropping}

Setelah hasil koreksi geometrik didapatkan selanjutnya dilakukan pemotongan atau cropping sesuai dengan batas administrasi Kabupaten Pasuruan berdasarkan peta vektor Bakosurtanal.

\section{Klasifikasi}

Klasifikasi dilakukan dengan memasukkan algoritma NDVI dan metode klasifikasi terbimbing tipe maximum likellihood dengan trainning sample

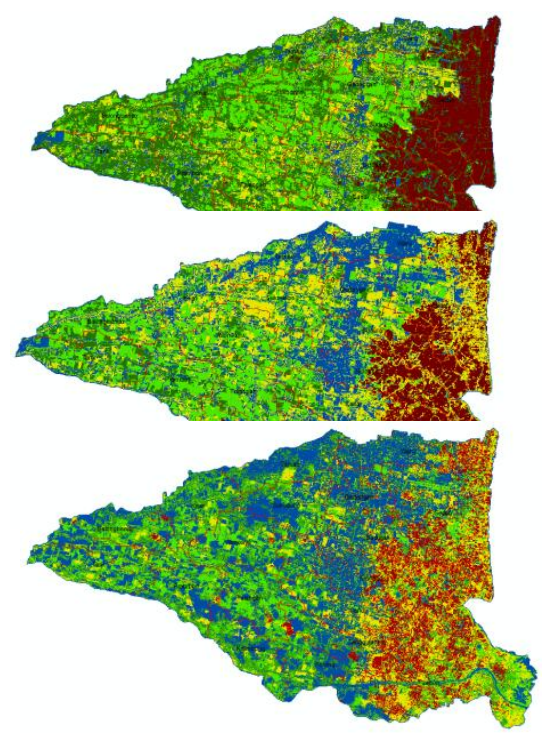

Gambar 6. Citra hasil klasifikasi

\section{ANALISA}

Berikut adalah perbandingan hasil klasifikasi supervised peruntukan lahan sawah tahun 2000, 2005 dan 2010

Tabel 3. Perbandingan hasil klasifikasi supervised peruntukan lahan sawah tahun 2000,2005 dan 2010

\begin{tabular}{cccc}
\hline Kelas & Tahun \\
& $2000(\mathrm{Ha})$ & $2005(\mathrm{Ha})$ & $2010(\mathrm{Ha})$ \\
\hline Belukar & 10487.16 & 19906.47 & 14361.72 \\
Pemukiman & 4481.73 & 17019.81 & 23091.70 \\
Sawah & 15858.00 & 15850.44 & 11337.55 \\
Tambak & 15606.9 & 13080.51 & 9676.56 \\
Tegalan & 25481.52 & 6054.75 & 13423.41 \\
\hline
\end{tabular}

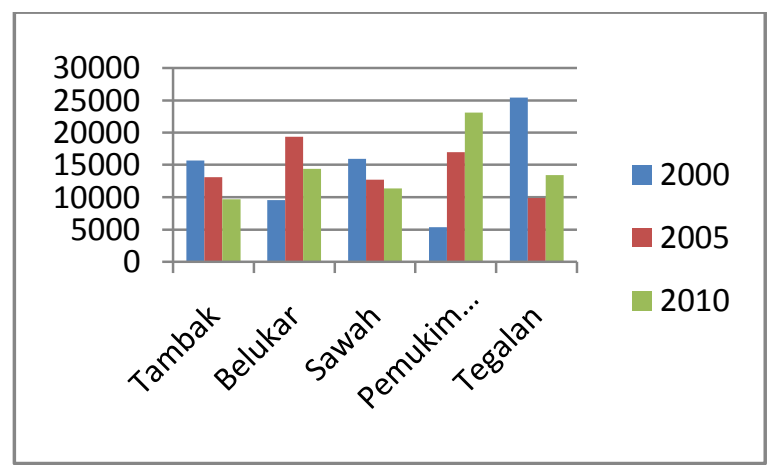

Gambar7. Grafik luas tutupan lahan pada tahun 2000, 2005 dan 2010 
Dari tabel dan grafik diatas, dapat diketahui luasan tiap kelas tutupan lahan mengalami kenaikan dan penurunan. Pada tahun 2000 dimana masih sangat sedikit sekali lahan pemukiman sehingga menyebabkan angka vegetasi sangat besar diantaranya tambak, sawah dan tegalan. Pada tahun 2005 terdapat angka kenaikan pada belukar, hal ini disebabkan karena pada waktu itu musim penghujan berlangsung berdasarkan pengambilan data oleh satelit, sehingga menyebabkan banyaknya vegetasi belukar atau tanaman liar berkembang, selain itu, angka kenaikan pemukiman juga mengalami kenaikan sangat pesat seiring jumlah lahan sawah yang berkurang tiap tahunnya. Pada tahun 2010 klasifikasi mengalami kesulitan karena data citra pada waktu itu sebagian daerah tertutup awan, sehingga warna antara awan dan pemukiman mengalami kemiripan. Pada sektor sawah terus mengalami penurunan dari tahun ke tahun.

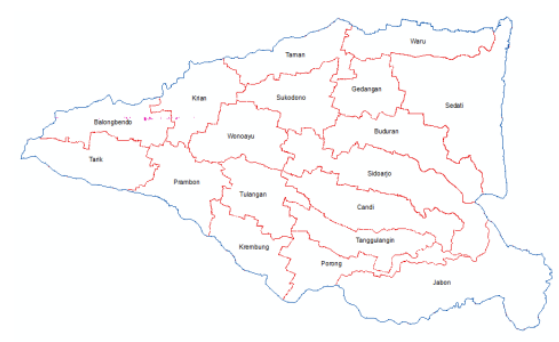

Hasil dari overlay diatas antara kelas sawah dan kelas pemukiman, maka akan didapat luasan perubahan dimana area kelas sawah telah berubah menjadi area kelas pemukiman seluas $0,81 \mathrm{Ha}$. Perubahan kelas sawah dari tahun 2000 ke tahun 2005 hanya menurun 7,56 Ha

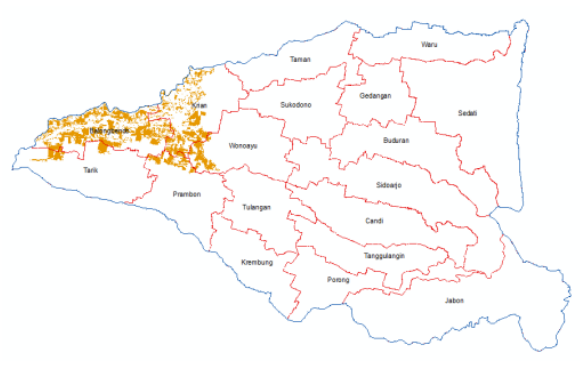

Hasil dari overlay diatas ini menunjukkan bahwa terdapat pengalihan fungsi lahan pertanian menjadi lahan pemukiman seluas $716,58 \mathrm{Ha}$. Perubahan kelas sawah dari tahun 2005 ke tahun 2010 telah menurun 4512,89 $\mathrm{Ha}$

\section{KESIMPULAN DAN SARAN}

\section{Kesimpulan}

a. Luas yang didapat pada tahun 2000 adalah 15858,00 Ha, tahun 2005 adalah 15850,44 Ha dan tahun 2010 adalah 11337,55 Ha

b. Pada kelas sawah dari tahun 2000 sampai tahun 2010 terus mengalami penurunan, pada tahun 2000 - 2005 sebesar 7,56 Ha dan $2005-2010$ sebesar 4512,89 Ha.

\section{Saran}

a. Penginderaan jauh merupakan metode baru yang dapat digunakan sebagai data pembanding dengan data yang ada

b. Perlu dilakukan koordinasi dengan pihak terkait diantaranya Dinas Pertanian dan BPS untuk penyusunan standar operasioanl dalam pembuatan data luas lahan pertanian padi.

\section{DAFTAR PUSTAKA}

Adimihardja A., Wahyunto dan Rizatus S. 2004. Gagasan Pengendalian Konversi Lahan Sawah Dalam Rangka Peningkatan Ketahanan Pangan Nasional. Prosiding Seminar: Multi Fungsi Pertanian dan Konservasi Sumberdaya Lahan, di Bogor, 18 Desember 2003 dan 7 Januari 2004. halaman 47-64. Puslitbang Tanah dan Agroklimat. Bogor.

Campbell, J.B. 1987. Introduction to Remote Sensing. Virginia Polytechnic Institute. New York - London : The Gullford Press.

Dinas Pertanian, Perkebunan dan Peternakan Kabupaten Sidoarjo, BPS dan BAPPEKAB SIDOARJO 2005. Sidoarjo Dalam Angka. Sidoarjo.

Lillesand, T.M., and R.W.Keifer. 1994. Remote Sensing and Image Interpretation. Third Edition. John Willey \& Sons, Inc, United States of America.

Noer, M.A. 2011. Aplikasi Sistem Informasi Geografis dan Penginderaan Jauh Untuk Monitoring Area Sawah dengan Data Multitemporal (Studi Kasus : Area Sawah Kabupaten Sidoarjo. Fakultas Teknik Sipil dan Perencanaan Wilayah, Institut Teknologi Sepuluh Nopember, Surabaya.

Pahlevi, A.M. 2009. Analisa Sedimentasi Di Muara Kali Porong Akibat Pembuangan Lumpur Lapindo Menggunakan Citra Satelit ASTER. Fakultas Teknik Sipil dan Perencanaan 
Wilayah, Institut Teknologi Sepuluh Nopember, Surabaya.

PemKab Sidoarjo

Online, URL:http://www.sidoarjokab.go.id. html Dikunjungi pada tanggal 1 Februari 2012.

Prahasta, E. 2008. Remote Sensing Praktis Penginderaan Jauh \& Pengolahan Citra Dijital dengan Perangkat Lunak ER Mapper, Informatika, Bandung.

Sanjaya, H. 2004. Zamrud Khatulistiwa: teropong dari luar angkasa sampai laut dalam. P3-TISDA
BPPT dan SEACORM - Badan Riset Kelautan dan Perikanan. Jakarta.

Sutanto. 1994. Penginderaan Jauh. Gadjah Mada University Press. P.O.Box 14 Bulaksumur, Yogyakarta

Wahyunto, Murdiyati, S.R. dan Ritung, S. 2004. Aplikasi Teknologi Penginderaan Jauh dan Uji Validasinya Untuk Deteksi Penyebaran Lahan Sawah dan Penggunaan/Penutupan Lahan, Bogor. Soil Research Institute, CSARD of IAARD 